\title{
Sustainable tourism and economic growth nexus in Kenya: policy implications for post- Covid-19
}

\section{Kipkosgei Bitok}

School of Hospitality, Tourism and Leisure Studies

Kenyatta University, Kenya

kipsabi02@gmail.com; bitok.kipkosgei@ku.ac.ke

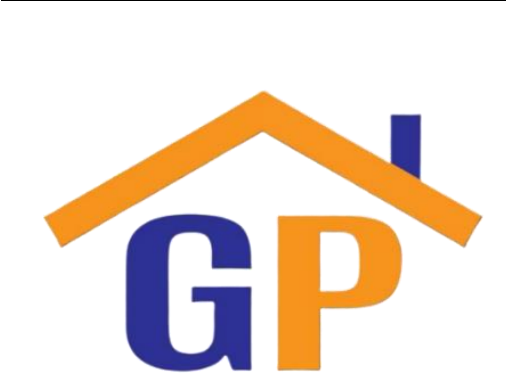

Article History

Received on 17 August 2020

$1^{\text {st }}$ Revision on 22 August 2020

$2^{\text {nd }}$ Revision on 18 September 2020

Accepted on 22 September 2020

\begin{abstract}
Purpose: The COVID-19 global pandemic has caused an unprecedented socio-economic impact. It has also raised our awareness of the role sustainability needs to play in our economic activities. This study investigated how sustainable tourism has contributed to economic growth in Kenya.

Research Methodology: Eviews 10 software was used to analyze the time-series data. Drawing on data from 1995 to 2020, Johansen co-integration, Granger causality, and regression approaches were used.
\end{abstract}

Results: The study found out that tourism employment and GDP are positively connected to economic growth in Kenya. The causality was unidirectional from economic growth to tourism contribution to GDP and employment, with a long-run linkage of the study determinants.

Limitations: Since this research used the secondary sources of data, similar studies in the future may concentrate on the primary data sources to investigate the relationship between tourism employment and economic advancement.

Contribution: At the new normal in the post-Covid-19 period, the study suggests that legislators and tourism policymakers should focus on the policies aimed at promoting sustainable tourism. Sustainable tourism should be managed following the three pillars of sustainability.

Keywords: Development, Domestic, Moderate, Regional, Scenario

How to cite: Bitok, Kipkosgei. (2019). Sustainable tourism and economic growth nexus in Kenya: policy implications for postCovid-19. Journal of Sustainable Tourism and Entrepreneurship, 1(2), 123-138.

\section{Introduction}

This section is composed of the background of the study and the statement of the problem. It relates sustainable tourism and the growth of the economy on the global, regional and national perspectives.

\subsection{Background of the study}

The growth and development of the global tourism industry have engendered a new paradigm of sustainable socio-economic advancement. The thought behind sustainable tourism is driven by visits to destinations without harming the natural environment or local communities. Tourism may incorporate visits to places of interest using local transportation, and some of the activities include lodging, relaxation, entertainment, shopping, and food (Manzoor, Wei, Asif, Haq \& Rehman, 2019). In most cases, people travel for recreation, commerce, and to meet family or friends. Significantly, the 
focus on sustainability raises debates on the benefits of tourism to the national economy and livelihoods.

According to the International Labor Organization (ILO) (2016), tourism has become a significant driver of employment generation and the pivot for growing the economy. The direct, indirect, and induced impact of Travel and Tourism globally accounted for \$8.9 trillion (10.3\%) of global GDP in 2019. While generating more than 330 million jobs, it indicates that the industry accounts for 1 in every 10 jobs available around the world (WTTC, 2020). Numerous countries today have tourism remaining as a significant generator of income through job provision and business incubation within the formal and informal sectors (Manzoor et al., 2019). It is only through sustainable tourism that the advancement of this important sector can improve social responsibility and create meaningful employment opportunities for all.

The decline in the global travel and tourism market in 2020 is attributable to the coronavirus (COVID-19) pandemic, and estimates show that 100.8 million jobs worldwide were lost. The Asia Pacific region bears the biggest brunt of the adverse impacts of COVID-19 having approximately 63.4 million job losses. Meanwhile, Africa's employment is forecasted to drop by 7.6 million as it comes as the fourth hardest-hit continent (Statista, 2020). A moderate scenario is exhibited in Jamaica with a possible 11 percent loss of Gross Domestic Product (GDP), even as tourism in the country contributes 20 percent in the gross domestic product (UNCTAD, 2020). In an extreme situation that the whole tourism industry stops for about twelve months, employment in Jamaica will fall 44 percent given that unskilled employees in the tourism industry occupy a greater share. The high unemployment aggravated by the coronavirus pandemic has come as an unprecedented crisis for the tourism economy and caused significant losses in GDP (OECD, 2020). Humanitarian crises, especially the coronavirus pandemic, have negatively affect people's lives and triggered a global economic downturn. The tangible impacts of the pandemic to the tourism sector have been realized in regions, countries, and cities where tourism forms a core part of the economy. Hence, this study seeks to contribute to discussions and decisions on tourism policy at the local, national, as well as at the international levels. This study also aims at complementing prior studies using advanced econometric methodologies which can be translated into actionable policy situations in the real world.

According to Trading Economics (2020), the Kenyan GDP per capita is expected to reach $\$ 1090.00$ by the end of 2020. The Kenya GDP per capita, in the medium-term, is projected to trend around $\$ 1230.00$ in 2021 and \$1350.00 in 2022. The tourism sector in Kenya earned KES163.56 billion ( $\$ 1.54$ billion) in 2019 and is among the country's leading contributors of foreign exchange (Obulutsa \& Mohamed, 2020). Although it expects its economy to grow by $1 \%$ in 2020 , Kenya may be worse off after it lost KES80 billion (\$752 million) in tourism revenues. This represents half of the total revenues generated in 2019 and these losses are greatly attributed to the portion of the tourism sector in comparison to GDP (UNCTAD, 2020). The dependency and interlink of supply among the tourism sectors have seen people and businesses rapidly shift from tourism to other industries. Just like Jamaica, the Kenyan situation is a moderate scenario in which it stands to lose out 5 percent in GDP due to the coronavirus pandemic. The dramatic contraction in the tourism industry is expected to create massive unemployment and displacement of workers. While the displaced labour force may migrate to other sectors in a country, employment in the tourism industry during the economic downturn will remain elusive. Alternatively, work opportunities may arise in sectors not related to tourism, attracting a proportion of migrating workers from the industry.

Going forward, the industry must rethink its policy strategy regarding shortening the recovery period after the pandemic and sustaining tourism even as the crisis bites hard (Magical Kenya, 2020). Although international tourism is expected to slump in the short-term, the effects will be felt over the long-term. Magical Kenya has a recovery strategy where communities are seen as critical to the growth of tourism, and proposes a number of possible areas to explore in order to keep tourism 
businesses running. Domestic and regional tourism will stand out as the first point of call, and Kenya should leverage on digitization and reimage ways of enhancing tourism sustainability.

\subsection{Statement of the problem}

Sustainable tourism presents an essential engine for social and economic development, and has a great capability for stimulation of employment and enterprise, especially for youth and women (ILO, 2017). Over the last decades, the measurement of sustainable tourism has been expanded and diversified even as debates on the appropriate approaches continue. In spite of this, the significance of sustainable tourism to employment and GDP is mostly underestimated in policy-making and strategy in tourism development. Furthermore, the susceptibility of tourism, especially during coronavirus pandemic, shows that minimal attention is given to its positive contribution to economic growth, trade, and employment. According to UNCTAD (2020), prolonged lockdown due to COVID-19 containment measures reduced supply, in addition to the demand for export products, which had a combined negative impact on the economic situation of several countries. The Kenyan tourism sector, based on the Ministry Of Tourism and Wildlife Strategic Plan 2018-2022, shows that the sector has experienced growth over the last seven years (Republic Of Kenya, 2020a). However, it still faces global, regional, and local challenges warranting policymakers' attention. The threat of infectious diseases such as Ebola and COVID 19 Pandemic to the Kenya tourism industry is real, and the longterm risk measures are required. This study, therefore, will contribute significantly to the review of the Draft Revised National Tourism Policy on Enhancing Sustainable Tourism in Kenya (Republic of Kenya, 2020b), including future policy discussions and decisions.

\section{Literature review and hypothesis development}

This section elaborates on sustainable tourism and economic growth. It also postulates the study hypotheses which serve as a premise for empirical review.

\subsection{Economic growth}

The Sustainable Development Goals (SDGs) encourage sustainable advancement of the economy, technological improvement, and productivity at higher levels of performance (UNDP, 2020). Encouraging entrepreneurship and job creation is a gateway to achieving full and productive employment, decent work, and fulfillment of goals of Vision 2030. In Kenya, the tourism industry has the possibility to add, directly or indirectly, towards achieving the Vision 2030 Agenda through SDGs. Emphasizing on goal 8, Kenya can promote an inclusive and sustained economic growth if tourism will be taken as a prime and essential sector (Republic of Kenya, 2020b). The Ministry of Tourism and Wildlife in its Draft Revised National Tourism Policy, 2016 on Enhancing Sustainable Tourism in Kenya seeks for diversification of tourism in the light of the changing environment due to the Covid-19 pandemic. The policy document proposes the provision of incentives for domestic tourism. Domestic tourism is the future of Kenya's tourism industry with immense potential to become a strong sub-sector through education and awareness creation.

Kenya has experienced slower economic growth relative to some of the East African Community (EAC) countries over the last fifteen years (The Parliament of Kenya, 2020). Its share of EAC GDP declined from $42 \%$ in 2005-2007 to 39\% over the last five years. Kenya's per capita GDP (current prices) grew from KES47000 in 2005 to KES204000 in 2019. Focus Economics Consensus Forecast panelists forecast GDP growth accelerating to 5.3\% in 2021 even though the GDP growth in 2020 was a paltry $1.0 \%$ (Kenya Economic Outlook, 2020). The growth will be supported by investments under the "big four," growth in tourism and exports, and public investment to develop infrastructure. Despite the coronavirus pandemic, the Kenyan government continues to focus on providing continuous, equitable, accessible, and quality essential health care services (Ministry of Health, 2020). The government's commitment to revitalizing the Primary Health Care systems in Kenya is a critical pillar in the realization of Universal Health Coverage. However, there is no report on the progress of key policy reforms under this pillar such as the medical tourism strategy (The Parliament of Kenya, 2020).

\subsection{Sustainable tourism}


Kenya, while advancing the long term Vision 2030 development agenda, considers the tourism sector as a top priority area for driving a double-digit economic increase and development (Republic of Kenya, 2020a). The Ministry of Tourism and Wildlife in Kenya reviewed its Strategic Plan of 20182022. Kenya's international arrivals contracted by $4.5 \%$ from $1.52 \mathrm{M}$ to $1.45 \mathrm{M}$ between 2018 and 2019, but tourism earnings grew by $27.6 \%$ from KES94 billion to KES119.9 billion. This increase has largely been driven by domestic tourism after the local Kenyan tourist base expanded by $35.1 \%$ from 2.7 million to 3.6 million over the past two years. According to the National Tourism Blueprint 2030, there are over 180 wildlife hotel and resort establishments in Kenya comprising 57\% of the total bed capacity that is star rated. There is already a Wildlife Conservation and Management policy in place to protect wildlife migratory corridors, recruit more game rangers, install electric fences and develop paved roads. While pursuing these goals, Kenya remains cognizant of several threats such as security/terrorism, poaching, negative publicity, and lack of diversification. Other challenges include inadequate funding, drought, escalating incidences of human-wildlife conflicts, Ebola outbreak, low product quality, climate change, and climate variability. The effective achievement of these goals will depend on how the tourism sector tackles these imminent challenges.

The Kenyan tourism industry accounts for over $10 \%$ of total employment, $18 \%$ Foreign Exchange earnings, and $11 \%$ in the form of taxes. The sector also contributes $9 \%$ to GDP and is a major revenue source for the government. The Kenyan government collects most of the money from license fees and park entry fees (Republic of Kenya, 2020a). Chapter one of Kenya's Draft Revised National Tourism Policy of the year 2020 underscores the importance, and share of the tourism sector to the local and national economy, and employment creation. The covid-19 crisis is characterized by an unexpected rise in unemployment, exacerbated to some extent by containment measures by the government (UNCTAD, 2020). The ban on international travel, as a COVID-19 containment measure, significantly reduced activity in this sector. To make it worse, local tourism diminished due to lockdown and the closure of bars and restaurants, except for takeaway services. Given that majority of workers in the Kenyan tourism industry are daily wage earners, it was easy for the employers to lay them off or have them take unpaid leave (Parliamentary Budget Office, 2020). Therefore, this study seeks to contribute to discussions and decisions on tourism policy at the local, national, as well as at the international levels.

\subsection{Measurement of variables}

\section{Measuring economic growth}

Kibara, Odhiambo, and Njuguna (2012) analyzed the Kenyan annual data from 1999 to 2010 to establish the dynamic links of tourism sector development with economic growth. The study sought to respond to an important phenomenon: is tourism development in Kenya pro-growth? The researchers used a multivariate test to examine these linkages and also incorporated trade, using an ARDL-bounds testing approach, to establish the association of tourism development and the growth of the economy. Their study findings identify tourism development as having a unidirectional causality on economic growth, irrespective of causality estimates being a short-term or long-term. The World Development Indicators used measures the growth of the economy $(\mathrm{y} / \mathrm{N})$ in terms of real GDP per capita. Similarly, Ivanov and Webster (2007) sought to develop a methodology for measuring how tourism contributes to the growth of the economy using data from Greece, Spain, and Cyprus. Utilizing data spanning 1997 to 2004, the authors established that real GDP per capita ideally measures economic growth. Their methodology is compared with other existing methodologies such as econometric modeling and Computable General Equilibrium models of economic growth. GDP per capita is adopted in this study to measure economic growth.

\section{Measuring sustainable tourism}

Previous research has suggested a comprehensive set of indicators relating to sustainable tourism, but these were not chosen or established within a statistical context. At this point, no definitive discussion has been held about the types of sustainable tourism indicators that could be identified (UNCEEA, 2016). The current proposals, derived from tourism GDP (TGDP) and tourism employment, are meant to measure sustainable tourism. The two identified indicators are meant to cover in part, the social and 
economic dimensions of sustainable tourism. The measurement indicators that capture the environmental dimension presently are riddled with inadequate capacity, and this makes tourism employment and tourism contribution to GDP to be significant indicators for measuring sustainable tourism.

Maftuhah and Wirjodirdjo (2018) conducted research that reviewed and mapped several studies associated with the main pillars of sustainable tourism. By presenting the distribution of 40 publications, the authors established that sustainability aspects were in the majority (28\%) of researches that simultaneously discussed social, cultural, and economic perspectives. The second and third-ranking aspects tied at $25 \%$, in which case the researches discussed social-culture, and the three pillars of sustainability at once respectively.

\subsection{Empirical review of literature review}

The interconnection of tourism development and the growth of the economy has generated a number of studies in recent years (Kibara et al., 2012). The authors observe that there has been no consensus on the causality direction between these two critical economic determinants. This happens despite several studies having been conducted to expound on the linkage of tourism development with economic growth. According to Kibara et al., (2012) some studies have shown that real sector development leads to the invasion sector development, as others decreed that tourism sector growth has triggered economic growth. Between these two extremes, there are those who posit that these sectors share Granger-causality effects. Their study confirmed that tourism contributes to economic growth in Kenya. It is through the use of novel empirical techniques that their study elaborates on the dynamic causal links of tourism with economic development in Kenya. Various studies have linked tourism and the growth of the economy as presented in Table 1. However, no study has provided a link between sustainable tourism and economic growth, a gap that this study seeks to fill.

Table 1: Measurement of Research Determinants

\begin{tabular}{|c|c|c|c|c|c|}
\hline \multirow{2}{*}{$\begin{array}{l}\text { Authors } \\
\text { (year) }\end{array}$} & \multicolumn{2}{|l|}{ Measurement } & \multirow[t]{2}{*}{ Analysis } & \multirow[t]{2}{*}{ Timeframe } & \multirow[t]{2}{*}{ Country } \\
\hline & Variable 1 & Variable 2 & & & \\
\hline $\begin{array}{ll}\text { Manzoor } & \text { et } \\
\text { al. }(2019) & \end{array}$ & $\begin{array}{l}\text { Sustainable } \\
\text { tourism (Annual } \\
\text { growth } \\
\text { tourism) }\end{array}$ & $\begin{array}{l}\text { Employment } \\
\text { (Employment } \\
\text { rate); Economic } \\
\text { growth (GDP) }\end{array}$ & $\begin{array}{l}\text { Regression and } \\
\text { Johansen } \\
\text { cointegration }\end{array}$ & 1990 to 2015 & Pakistan \\
\hline $\begin{array}{l}\frac{\text { Maden, }}{\text { Bulgan, }} \text { and } \\
\frac{\text { Yildirim, }}{(2019)}\end{array}$ & $\begin{array}{l}\text { Tourism effects } \\
\text { (Tourism } \\
\text { income) }\end{array}$ & $\begin{array}{l}\text { Economic growth } \\
\text { (GDP per capita) }\end{array}$ & $\begin{array}{l}\text { Time series } \\
\text { ARDL bound } \\
\text { tests }\end{array}$ & $1980-2016$ & Turkey \\
\hline $\begin{array}{l}\text { Kibara et al., } \\
(2012)\end{array}$ & $\begin{array}{l}\text { Tourism } \\
\text { development } \\
\text { (international } \\
\text { tourist arrivals) }\end{array}$ & $\begin{array}{l}\text { Economic growth } \\
\text { (Real GDP per } \\
\text { capita) }\end{array}$ & $\begin{array}{l}\text { Time-series } \\
\text { ARDL-bounds } \\
\text { test }\end{array}$ & 1999-2010 & Kenya \\
\hline$\frac{\text { Akama }}{(2017)}$ & $\begin{array}{l}\text { International } \\
\text { tourism receipts }\end{array}$ & $\begin{array}{l}\text { Economic growth } \\
\text { (GDP growth } \\
\text { rate) }\end{array}$ & $\begin{array}{l}\text { OLS regression, } \\
\text { Co-integration } \\
\text { and Granger } \\
\text { causality test }\end{array}$ & $1980-2013$ & Kenya \\
\hline$\underline{\text { Ohlan (2017) }}$ & $\begin{array}{l}\text { Tourism } \\
\text { development } \\
\text { (international } \\
\text { tourism receipts } \\
\text { per capita) }\end{array}$ & $\begin{array}{l}\text { Economic growth } \\
\text { (GDP per capita) }\end{array}$ & $\begin{array}{l}\text { Co-integration } \\
\text { Granger- } \\
\text { causation }\end{array}$ & 1960 to 2014 & India \\
\hline Phiri (2015) & $\begin{array}{l}\text { Tourism } \\
\text { development } \\
\text { (tourist receipts, } \\
\text { number of }\end{array}$ & $\begin{array}{l}\text { Economic growth } \\
\text { (GDP) }\end{array}$ & $\begin{array}{l}\text { Engle and } \\
\text { Granger } \\
\text { causality, linear } \\
\text { cointegration }\end{array}$ & 1995 to 2014 & $\begin{array}{l}\text { South } \\
\text { Africa }\end{array}$ \\
\hline
\end{tabular}




\begin{tabular}{|c|c|c|c|c|c|}
\hline & $\begin{array}{l}\text { international } \\
\text { tourist arrivals) }\end{array}$ & & & & \\
\hline$\frac{\text { Turgut and }}{\frac{\text { Y1lmaz }}{(2015)}}$ & $\begin{array}{l}\text { Tourism } \\
\text { (expenditures of } \\
\text { foreign tourists) }\end{array}$ & $\begin{array}{l}\text { Economic growth } \\
\text { (GDP) }\end{array}$ & $\begin{array}{l}\text { Unit-root test } \\
\text { Co-integration }\end{array}$ & $1980-2013$ & Greece \\
\hline$\frac{\text { Tabash }}{(2017)}$ & $\begin{array}{l}\text { Role of Tourism } \\
\text { Sector } \\
\text { (international } \\
\text { tourism receipts) }\end{array}$ & $\begin{array}{l}\text { Economic } \\
\text { Growth } \\
\text { (GDP) }\end{array}$ & $\begin{array}{l}\text { Unit Root Test, } \\
\text { Co-integration, } \\
\text { Granger } \\
\text { Causality Test }\end{array}$ & 1995 to 2004 & Palestine \\
\hline $\begin{array}{l}\text { Jayathilake, } \\
\underline{(2013)}\end{array}$ & $\begin{array}{l}\text { Tourism } \\
\text { (tourist arrivals) }\end{array}$ & $\begin{array}{l}\text { Economic growth } \\
\text { (GDP) }\end{array}$ & $\begin{array}{l}\text { Co-integration } \\
\text { and Causality } \\
\text { Analysis }\end{array}$ & 1967 to 2011 & Sri Lanka \\
\hline
\end{tabular}

Alhowaish (2016) used panel data for the period 1995-2012 to assess whether tourism advancement caused economic improvement in the Gulf Cooperation Council (GCC). Using a multivariate version, the research adopted a Granger causality panel analysis method to evaluate how tourism contributes to the economic boom in GCC nations in totality, and with individual countries. For the case of the entire GCC nations, the findings display a one-way Granger causality, in the direction of economic growth towards tourism growth. Additionally, the direction of economy-led tourism growth is currently being led by Saudi Arabia, Qatar, United Arab Emirates, and Kuwait. Bahrain had tourismled growth, and no causal linkage connecting tourism with economic development for Oman.

\section{Hypotheses}

This study hypothesizes that:

H01: Tourism contribution to GDP and economic growth are not statistically related.

H02: Employment in tourism and economic growth are not statistically related.

H03: Sustainable tourism and economic growth have no statistically significant relationship.

\section{Research methodology}

This section elaborates on the data variables and the methods used in analyzing data. It also includes the theoretical underpinnings of the study.

\subsection{Data and variables}

An analysis of the connection of sustainable tourism and the growth of the economy on the main macroeconomic variables is crucial. In this review study, the tourism contribution to GDP (TCGDP) was measured in US dollars and tourism contribution to employment (TCEMP) was measured by the number of jobs, with the data obtained from World Travel and Tourism Council, as shown in Table 2. GDP per capita (GDPPC) was rated in US dollars and data was obtained from the International Monetary Fund. All data collected were for the periods of 1995 to 2020, and the analysis is done using Eviews 10 software.

Table 2: Research Data

\begin{tabular}{|l|l|l|l|}
\hline Year & $\begin{array}{l}\text { TCGDP (Current USD } \\
\text { Billions) }\end{array}$ & TCEMP (thousands) & $\begin{array}{l}\text { GDP Per Capita } \\
\text { (Current USD) }\end{array}$ \\
\hline $2020 \mathrm{e}$ & 3.95 & 900 & -1.70 \\
\hline 2019 & 8.41 & $1,110.86$ & $1,997.55$ \\
\hline 2018 & 7.96 & $1,076.76$ & $1,830.59$ \\
\hline 2017 & 7.55 & $1,045.91$ & $1,683.95$ \\
\hline 2016 & 7.29 & $1,024.10$ & $1,522.29$ \\
\hline 2015 & 7.43 & $1,067.55$ & $1,453.30$ \\
\hline 2014 & 7.39 & $1,090.57$ & $1,431.32$ \\
\hline 2013 & 7.21 & $1,086.93$ & $1,318.79$ \\
\hline 2012 & 7.41 & $1,147.28$ & $1,238.88$ \\
\hline
\end{tabular}




\begin{tabular}{|l|l|l|l|}
\hline 2011 & 7.09 & $1,127.33$ & $1,054.98$ \\
\hline 2010 & 6.52 & $1,050.64$ & $1,038.95$ \\
\hline 2009 & 5.6 & 947.318 & 982.00 \\
\hline 2008 & 6.14 & $1,039.81$ & 978.45 \\
\hline 2007 & 6.82 & $1,130.96$ & 895.23 \\
\hline 2006 & 6.43 & $1,101.35$ & 743.44 \\
\hline 2005 & 6.23 & $1,096.43$ & 621.28 \\
\hline 2004 & 5.52 & 995.34 & 549.16 \\
\hline 2003 & 4.29 & 785.38 & 524.74 \\
\hline 2002 & 3.19 & 582.54 & 473.99 \\
\hline 2001 & 3.45 & 612.51 & 479.60 \\
\hline 2000 & 3.65 & 653.01 & 479.30 \\
\hline 1999 & 5.84 & $1,016.39$ & 500.11 \\
\hline 1998 & 5.28 & 905.32 & 564.74 \\
\hline 1997 & 4.92 & 839.01 & 507.78 \\
\hline 1996 & 4.26 & 700.64 & 516.17 \\
\hline 1995 & 4.83 & 795.03 & 468.00 \\
\hline
\end{tabular}

Data from 1995 to 2020 for tourism contribution to GDP and employment (WTTC, 2020), and GDP per capita (IMF, 2020). Meanwhile, the 2020 data is an estimate.

\subsection{Unit root test}

Examining whether there is stationarity is the initial step of time series (Tabash, 2017). Baumöhl and Lyócsa (2009) point out that the regression results are simply misleading when the dependent and independent time series are non-stationary. Time series data requires separation from all effects for greater accuracy of results and correct model evaluation (Manzoor et al., 2019). Logarithms of time series were computed considering that the series needed to be stationary. The Augmented DickeyFuller (ADF) was employed to assess whether GDP per capita, tourism contribution to employment, and tourism contribution to GDP series were stationary.

\subsection{Co-integration test}

This study employed the procedure developed by Johansen and Juselius (1990) to investigate the long-run relationship between variables. By conducting co-integration testing using the vector autoregression (VAR) approach, stationarity of the variables was established. After the determinants became stationary at the difference, the second step was to use Johansen and Juselius co-integration to test for co-integration. Johansen and Juselius formulated the trace test and the maximal eigen-value test to establish the number of the co-integrating vectors.

\subsection{Granger causality test}

In the event that two variables are co-integrated, as established by Granger (1988), then there must be at least a unidirectional causation. The Granger causality test allows researchers to statistically examine the causality direction between two variables. It was developed to predict present values of variable $\mathrm{y}$, checking whether or not the inclusions of past values of a variable $\mathrm{x}$ do or do not help. Granger causality test was carried out using estimation of the equations with least-squares method, and it relies on time series data.

\subsection{Regression analysis}

The linkage between sustainable tourism and economic growth established using a regression analysis technique is modified from (Manzoor et al., 2019). This study analyses the interconnection of tourism contribution to GDP and employment, and economic growth in Kenya. 


\subsection{Theoretical perspective}

\section{Three Nested Dependencies}

Dartmouth (2015) observed that the three-nested-dependencies model is a reflection of the codependent reality. For example, one would have to answer (Yes) if one were to ask if the devastating effect of COVI-19 in Kenya was listed as either an economic disaster, environmental disaster, or a social disaster. The response is a confirmation that human society is subsidiary and entirely owned by the environment. It is an indication that humans thrive under clean water, healthy food, fresh air, fertile soil, among other natural resources. Without these natural provisions, human society and the underlying economy cannot survive. The model of the three-nested-dependencies gives emphasis for people to decide how they are going to exchange goods and services. Because people create economies, then they decide the appropriate economic model to use, and whether or not the changes to the models are necessary to improve the quality of their lives. Sustainability is considered the new norm for every part of every economic sector and is no longer a niche in tourism alone (UNWTO, 2020).

According to Dushenko, Bjorbaek, and Steger-Jensen (2019), the empirical testing of the model is proof that the economic benefits of sustainable tourism are founded on social and environmental factors. It may be difficult to obtain a method of turning strategic sustainable tourism objectives at project-specific levels into concrete action. This means that the layout of the abstract sustainability models and the case-study outcomes are likely to conflict with one another. Consequently, using the qualitative study is a clear proof that decision-makers' strategic priority remains to be the economic issue despite the actual fact that the subject of sustainable development and environmental concerns are increasing in popularity.

\section{Sustainable Development}

Sustainable development theory combines the distinct goals of sustainability and development (Manzoor et al., 2019). Sustainable development advances improvements that meet the desires of the current times and balances the capability of humanity in the future to fulfill what they need (WCED, 1987). Essentially, this theory combines the theories of sustainability and development. Sustainable development (SD) has turned out to be a fundamental method that provides direction to the world's social and economic transformation (Longyu, Linwei, Fengmei, and Lijie, 2019). Longyu et al. (2019) note that the popularity of developmental regulations and policies mainly specializing in economic boom accelerated the frequency of serious environmental challenges. Besides, tourism could pose threats to the protection of cultural and environmental resources, which are important for attracting travelers. One lesson learned is, reducing the disparities between actual and expected sustainability in tourism will require the taxation of poor environmental impacts and designing proactive environmental policies (Dushenko et al., 2019). The Covid-19 crisis presents an opportunity to achieve a more sustainable and resilient future and rethinking the tourism system (OECD, 2020). In the long run, UNCTAD (2020) is optimistic that international tourism will be possible to return within 19 months to pre-pandemic levels. Policy intervention is needed to avoid the return to the setbacks of tourism management, and to address the structural problems of the sector. Besides advancing key priorities, tourism management is expected to embrace digitalization and promote connectivity. Inculcating sustainable development values will be advanced by institutions such as higher education and government training centers (Maingi, 2020).

\section{Results and discussions}

This section presents the results and the discussion of the study. It consists of descriptive statistics, diagnostic tests, regressions and discussions.

\section{Descriptive Statistics}

This section presents the findings of descriptive statistics employed to measure the central tendency, dispersion and distribution as well as the Jarque-Bera test for normality. Economic sustainability of tourism was measured as total contribution of tourism to GDP in current USD dollars, social sustainability of tourism as total contribution of tourism to employment, and economic growth as GDP per Capita in current dollars. These statistics are shown in Table 3. 
Table 3: Descriptive Statistics

\begin{tabular}{lllll}
\hline Statistical Measure Billions) & $\begin{array}{c}\text { TCGDP } \\
\text { Mean }\end{array}$ & $\begin{array}{c}\text { USD } \\
\text { TCEMP }\end{array}$ & $\begin{array}{l}\text { GDP } \\
\text { (Current USD) }\end{array}$ & Capita \\
Median & 5.948846 & 958806.3 & 917.4197 \\
Max. & 6.186000 & 1031955. & 819.3325 \\
Min. & 8.414000 & 1147280. & 1997.550 \\
Std. Dev. & 3.191000 & 582536.0 & -1.700000 \\
Skewness & 1.510691 & 172779.2 & 508.8772 & \\
Kurtosis & -0.302429 & -0.924405 & 0.486516 \\
Jarque-Bera & 1.927769 & 2.559113 & 2.321620 \\
Probability & 1.641826 & 3.913521 & 1.524238 & \\
\hline
\end{tabular}

The results in table 3 show that the average GDP per capita growth from the year 1996 to 2020 was USD 917.4197. The minimum and the maximum GDP per capita growth rate between 1996 and 2020 were USD 1997.550 and USD -1.700000 respectively. The sharp decline in the GDP per capita in 2020 may be attributed to the economic effects of the global Covid-19 disease outbreak. Its standard deviation was 508.8772 which indicated that GDP per capita varied throughout the period of measurement. The Jarque-Bera test had a probability value of 0.466676 and Kurtosis of 2.321620 which implies that $\alpha=0.05$, the null hypothesis of normality of the data is accepted and the data is considered to be normal. According to Kline (2011), values of Skewness and Kurtosis are considered to be approximately normal if they lie within a range of $\leq 3$ and $\leq 10$ respectively. This data can therefore be subjected to parametric statistical analysis.

Further, the average total contribution of tourism to GDP in current USD billions was USD 5.948846 billion. The minimum total contribution of tourism to GDP during the period 1996-2020 was USD 3.191000 dollars, and the highest contribution to the economy was USD 8.414000 billion. The standard deviation was 1.510691 implying that TCGDP varied throughout the measurement period. Jarque-Bera test had a probability value of 0.440030 and Kurtosis of 1.927769 which implies that at $\alpha$ $=0.05$, the null hypothesis of normality of the data is accepted and the data is considered to be normal.

The average total contribution of tourism to employment was 582536 jobs, with the highest contribution being 1147280 jobs in 2012, and the lowest tourism contribution to employment of 582536 jobs so recorded in 2020 . The standard deviation was 172779.2 , implying that the total contribution of tourism to social sustainability varied throughout the measurement period, as shown in Table 4. The Jarque-Bera test had a probability value of 0.141315 and Kurtosis of 2.559113 which implies that at $\alpha=0.05$, the null hypothesis of normality of the data is accepted and the data is considered to be normal.

Table 4: Correlation analysis

\begin{tabular}{llll}
\hline \hline $\begin{array}{l}\text { Correlation } \\
\text { Probability }\end{array}$ & LOGGDPPC & TCGDP & LOGTCEMP \\
\hline $\mathrm{d}($ LOGGDPPC) & 1.000000 & & \\
& - & & \\
$\mathrm{d} 2$ (TCGDP) & 0.905359 & 1.000000 & \\
& $0.0000^{* * *}$ & ---- & \\
$\mathrm{d}($ LOGTCEMP) & 0.706124 & 0.917023 & 1.000000 \\
& $0.0001 * * *$ & $0.0000^{* * *}$ & ---- \\
\hline \hline
\end{tabular}

${ }^{*}$ Sig at $10 \%{ }^{* *}$ sig at $5 \%{ }^{* * *}$ sig at $1 \%$

KEY 
LOGGPDPC $=$ Log of Gross Domestic Product Per Capita

TTCGDP $=$ Total contribution of tourism to gross domestic product

LOGTCEMP $=$ Log of Total contribution of tourism to employment

The correlation results found that the total contribution of tourism to GDP and GDP per capita have a strong positive and significant association $(\mathrm{r}=0.905359, \mathrm{p}=0.0000<0.05)$. The positive sign of the correlation coefficient implies that the total contribution of tourism to GDP and GDP per capita move in the same direction, as tourism increases GDP per capita also increases.

Correlation results also showed that the total contribution of tourism to employment and GDP per capita have a strong positive and significant association $(\mathrm{r}=0.706124, \mathrm{p}=0.0000<0.05)$. The positive sign of the correlation coefficient implies that the total contribution of tourism to employment and GDP per capita move in the same direction, that is; as the total contribution of tourism to employment increases, GDP per capita also increases.

The findings of this study concur with those of Manzoor et al., (2019), who noted that tourism had a positive effect on economic increase and employment. Their research outcome confirmed that a positive correlation exists between employment and GDP, and tourism advancement. This implies that the total contribution of TCEMP and TCGDP increases as GDP per capita also increases.

\section{Unit Root Test Results}

Prior to running a regression analysis, most economic variables were non-stationary in nature. To establish whether the variables were stationary or non-stationary, it was important to undertake the $\mathrm{ADF}$ unit root test. This test is meant to avoid false regression results being generated through nonstationary series. The unit root results are presented in Table 5.

Table 5: Unit Root Tests

\begin{tabular}{lcclccc}
\hline $\begin{array}{l}\text { Variable } \\
\text { name }\end{array}$ & $\mathbf{1 \%}$ Level & $\mathbf{5 \%}$ Level & $\begin{array}{l}\mathbf{1 0 \%} \\
\text { Level }\end{array}$ & ADF test & Sig. & Comment \\
\hline d(logGDP per & & & & & & \\
capita) & -3.752946 & -2.998064 & -2.638752 & -3.517610 & $0.0168 * * *$ & Stationary \\
d2(TCGDP) & -3.752946 & -2.998064 & -2.638752 & -4.435187 & $0.0021 * * *$ & Stationary \\
d(TCEMP) & -3.769597 & -3.004861 & -2.642242 & -4.746407 & $0.0011 * * *$ & Stationary \\
\hline
\end{tabular}

${ }^{*}$ Sig at $10 \%{ }^{* *}$ sig at $5 \%{ }^{* * *}$ sig at $1 \%$

The natural logarithm of GDP per capita was not stationary at $1 \%, 5 \%$, and $10 \%$ levels of significance. However, upon conducting the first differencing of the variable, GDP per capita became stationary at $1 \%, 5 \%$, and $10 \%$ levels of significance. The total contribution of tourism to GDP was non-stationary at level and at first difference. However, at the 2nd level differencing, the total contribution of tourism to GDP became stationary and could be employed in generating the model of the paper. Further, the total contribution of tourism to employment was non-stationary at level. After 1 st differencing, the variable became stationary at $1 \%, 5 \%$, and $10 \%$ levels of significance and could be used in generating the model of the study.

This study draws similarity to the work of Akama (2017), which showed that all variables were nonstationary at level, being stationary at order one I(1) except for GDP/worker. Taking the second differencing for GDP/worker shows that it is stationary at the second difference.

\section{Co-integration Test}

A cointegration test is carried out in the case that variables are non-stationary, or have similar order of integration. By undertaking Johansen test, the study determined the long-run linkage between economic growth and sustainable tourism. Table 6 shows the Johansen Co-integration Test results.

Table 6: Test for co-integration 


\begin{tabular}{lllll}
$\begin{array}{l}\text { Hypothesized } \\
\text { No. of CE }(\mathrm{s})\end{array}$ & Eigenvalue & $\begin{array}{l}\text { Trace } \\
\text { Statistic }\end{array}$ & $\begin{array}{l}0.05 \\
\text { Critical Value }\end{array}$ & Prob.** \\
\hline \hline None $*$ & 0.904271 & 69.71931 & 29.79707 & $0.0000^{* * *}$ \\
At most $1 *$ & 0.541232 & 20.44838 & 15.49471 & $0.0082^{* * *}$ \\
At most $2 *$ & 0.176771 & 4.084937 & 3.841466 & $0.0433^{* *}$ \\
\hline \hline
\end{tabular}

Trace test portray 3 co-integrating equation(s) - 0.05 level

* signifies rejection of the hypothesis - 0.05 level

***MacKinnon-Haug-Michelis (1999) p-values

"Significant at $\alpha=0.10 ;{ }^{* *}$ significant at $\alpha=0.05 ;{ }^{* * * *}$ significant at $\alpha=0.01$

Null hypothesis: There is at least one co-integrating equation.

The Johansen Co-integration Test results in Table 6 shows that the probability value is $0.0000<0.05$, hence the null hypothesis that there is at least one co-integrating equation is rejected. However, the trace statistic is greater than the Critical Value $(69.71931>29.79707)$, and we reject the null hypothesis that there is at least one co-integrating equation. VECM is used to evaluate the short-run properties of the co-integrated series. Nevertheless, we directly precede to Granger causality tests and estimate OLS model to establish the causal links between variables and co-integration VECM is no longer required.

This study supports the work of Manzoor et al. (2019), who investigated the linkage between economic growth and annual tourism growth, in addition to employment. In this study, the maxeigenvalues and test-trace showed that the determinants (GDP, employment, and tourism growth) have a long-run connection.

\section{Granger Causality Test}

After finding the variables are not co-integrated, Granger causality test was employed to find out the direction and causality between TCGDP, TCEMP, and GDPPC. Table 7 shows the Pairwise Granger Causality Tests.

Table 7: Granger Causality Tests

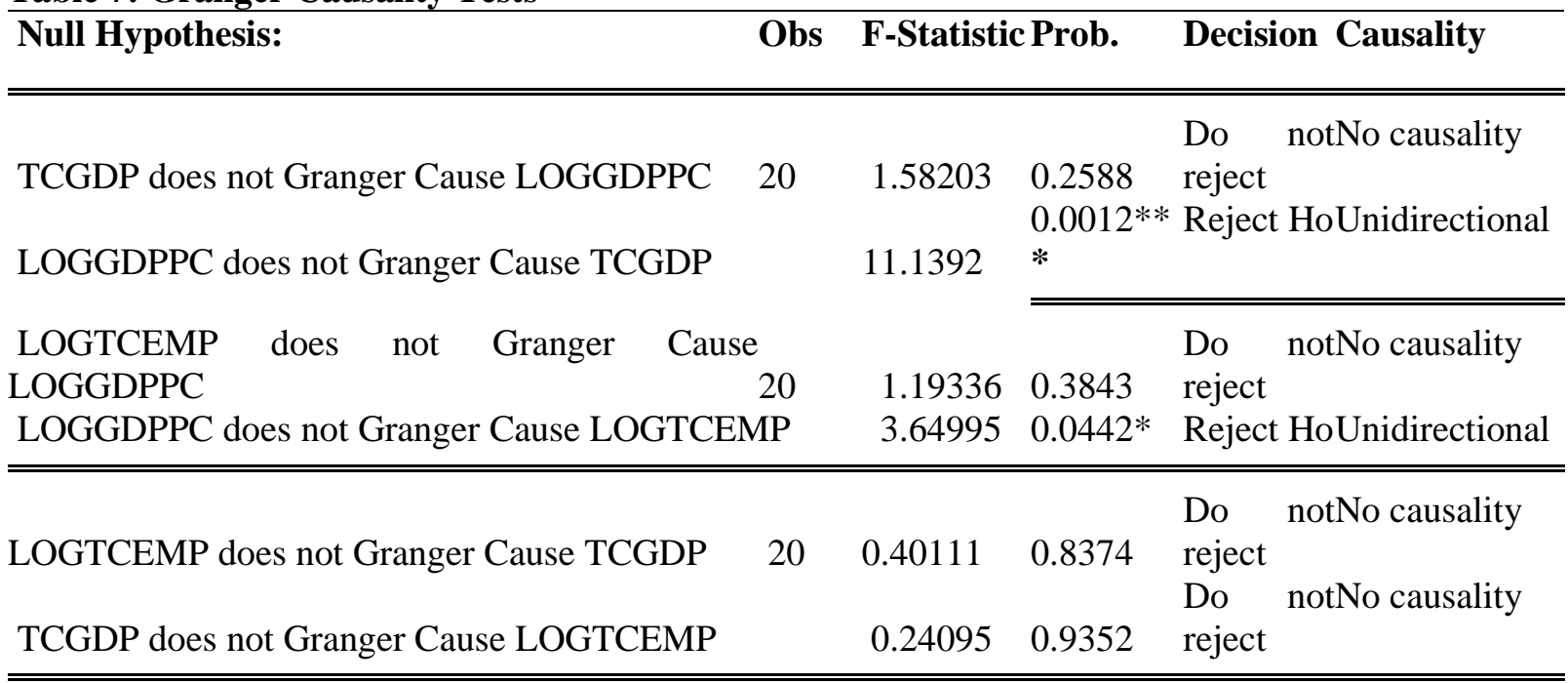

*Sig at $10 \%{ }^{* *}$ sig at $5 \%{ }^{* * *} \operatorname{sig}$ at $1 \%$

The findings do not reject the null hypothesis that the total contribution of tourism to employment does not granger cause GDP per capita. Owing to no existence of causality in the relationship, the study concludes that the total contribution of tourism to employment does not granger cause GDP per capita. Further, the null hypothesis that GDP per capita does not granger cause the total contribution 
of tourism to employment is rejected. As a result, the study concludes that GDP per capita granger causes the total contribution of tourism to employment, thus, unidirectional relationship.

The null hypothesis that the total contribution of tourism to employment does not granger cause the total contribution of tourism to GDP is not rejected. Hence, there is no causality relationship between TCEMP and TCGDP. Likewise, the null hypothesis that the total contribution of tourism to GDP does not granger cause the total contribution of tourism to employment is not rejected. Hence, there is no causality relationship between TCGDP and TCEMP.

According to Kibara et al. (2012), studies are showing that there has been no unanimous agreement on the causal connection of tourism development with economic growth. Alhowaish (2016) noted the existence of economy-led tourism growth direction in Saudi Arabia, Kuwait, United Arab Emirates, and Qatar. Similarly, this study confirms that that GDP per capita granger has a unidirectional causal relationship towards the TCGDP and TCEMP.

\section{Regression Analysis}

The study used OLS to estimate the model equation of the study. A multiple regression model was employed to determine the influence of TCGDP and TCEMP on GDP per capita. The hypothesis was tested using the p-value method and test of significance. Following the acceptance/rejection criterion, if the p-value is higher than 0.05 , we accept the $\mathrm{H} 0$, but if it is less than 0.05 level of significance, the $\mathrm{H} 0$ is rejected. The results are presented in Table 8.

Table 8: Regression model

Dependent Variable: LOGGDPPC

\begin{tabular}{lllll}
\hline \hline Variable & Coefficient & Std. Error & t-Statistic & Prob. \\
\hline \hline TCGDP & 0.546086 & 0.052039 & 10.49377 & $0.0000^{* * * *}$ \\
LOGTCEMP & -1.894899 & 0.375122 & -5.051422 & $0.0000^{* * *}$ \\
C & 29.51607 & 4.874586 & 6.055092 & $0.0000^{* * *}$ \\
\hline \hline R-squared & 0.916511 & Mean dependent var & 6.740009 \\
Adjusted R-squared & 0.908921 & S.D. dependent var & 0.500192 \\
S.E. of regression & 0.150955 & Akaike info criterion & -0.831506 \\
Sum squared resid & 0.501322 & Schwarz criterion & -0.685241 \\
Log likelihood & 13.39383 & Hannan-Quinn criter. & -0.790938 \\
F-statistic & 120.7534 & Durbin-Watson stat & 0.895868 \\
Prob(F-statistic) & 0.000000 & & \\
\hline \hline
\end{tabular}

${ }^{*}$ Sig at $10 \%{ }^{* *}$ sig at $5 \%{ }^{* * *}$ sig at $1 \%$

TCGDP and TCEMP in Table 8 were found to be satisfactory variables in GDP per capita. This fact is supported by the coefficient of determination also known as the $\mathrm{R}$ square of 0.916511 . This implies that tourism contribution to GDP and employment explains $91.7 \%$ variability of GDP per capita.

The results also revealed that tourism contribution to GDP and economic growth, measured using GDP per capita, have a positive and significant relationship $(\beta=0.546086, p=0.000<0.05)$. The regression of the coefficient implies that if tourism contribution to GDP increases by one unit, the GDP per capita increases by 0.546086 units. The null hypothesis was that tourism contribution to GDP does not influence economic growth. Results in Table 8 shows that tourism contribution to GDP and economic growth measured using GDP per capita are positively and significantly related, with $p$ value $=0.000<0.05$. The null hypothesis was therefore rejected and the conclusion made that tourism contribution to GDP influences economic growth. 
Model results also showed that total tourism contribution to employment and economic growth, measured using GDP per capita, have a negative and significant relationship ( $\beta=-1.894899$, $\mathrm{p}=0.000<0.05$ ). The regression of the coefficient implies that if tourism contribution to employment decreases by one unit, economic growth measured as GDP per capita decreases by -1.894899 units. The null hypothesis was that tourism contribution to employment does not influence economic growth. The null hypothesis was therefore rejected and the conclusion made that total tourism contribution to employment influences economic growth.

UNCTAD (2020) affirms that high unemployment contributes to significant losses in GDP. This implies that during the Covid-19, a greater part of the labour force may not be productive and does decrease economic growth. This is more pronounced from the impacts of Covid-19, where most of the employees in the tourism industry were affected by the containment measures to combat the spread of the pandemic, which limited their contribution to economic growth. The first hypothesis (H01) concluded that tourism contribution to GDP influences economic growth. Likewise, the second hypothesis (H02) also concluded that total tourism contribution to employment influences economic growth. Therefore, the third hypothesis (H03) that sustainable tourism does not influence economic growth was rejected and the conclusion made that sustainable tourism does influence economic growth.

The findings of this study also bear similarity to those of Manzoor et al (2019), who used regression analysis and found out that employment rate and annual tourism growth were positive and significantly related. From the regression analysis, this study confirms that sustainable tourism positively influences economic growth.

\section{Conclusion}

This study sought to analyze the linkage between sustainable tourism and economic growth in Kenya. Sustainable tourism was measured using the tourism contribution to GDP and employment, whereas economic growth was measured using the gross domestic product per capita. The study findings clearly depict a long-run linkage between tourism contribution to GDP and employment, and economic growth in Kenya. Similar to the United Arab Emirates, Kuwait, Saudi Arabia, and Qatar, Kenya's economic growth has a unidirectional causality on tourism contribution to GDP and employment. A decline in the economic growth in Kenya affects tourism's contribution to employment and GDP. The study confirms that high unemployment contributes to significant losses in GDP, especially during the Covid-19 pandemic period, hence, a greater part of the labour force becomes unproductive leading to a decrease in economic growth. It is imperative to engender sustainable tourism that safeguards employment and the GDP contribution ability of the tourism industry in order to advance national economic growth. Therefore, based on the three-nested theory and sustainable development theory, this study suggests that the Kenyan government should focus on socio-economic and environmental policies to promote sustainable tourism as a significant contributor to economic growth.

\section{Limitation and study forward \\ Limitation and future studies}

This study has some limitations, which may contribute to other researches in the future. Since this research used secondary sources of data, similar studies in the future may concentrate on primary sources of data to investigate the interrelation of tourism employment and the advancement of the economy. Future research can also relate the indirect and direct role of gross domestic product and employment in tourism on economic growth across all the tourism subsectors. Additionally, more studies need to explore the future of sustainable tourism - environmentally, socially, and economically at the regional level.

\section{Policy Implications}

Sustainable tourism is a driving force for the Kenyan economy. The travel and tourism industry brings lots of hope to the economy of the country in the post-Covid-19 phase, especially concerning the earnings, GDP, generation of employment, and economic advancement. If the Kenyan tourism 
industry is developed systematically and supported, it will reveal a natural splendor and benefits to future generations.

The Covid-19 pandemic is characterized by an almost unprecedented increase in unemployment. This study recommends responsible recovery for the tourism sector that is based on sustainability, in the short-term, and in the long-term. Tourism policymakers should appreciate the realization that sustainability must no longer be a niche part of tourism but must be the new norm for every part of our sector.

The COVID-19 heightens social tensions and engenders a general sense of insecurity within and among the population. It is necessary not only to strengthen social dialogue but also to build a strong basis for worker satisfaction as well as employer commitment at the enterprise-level.

The Kenyan Ministry of Health has noted that there is no report on the progress of key policy reforms under the tourism pillar such as the medical tourism strategy. The Ministry of Tourism and Wildlife should act with speed to develop and implement a medical tourism strategy for Covid-19, among other infectious diseases with global or national impacts.

With Covid-19 health restrictions still existing between countries, domestic tourism is expected to resume faster than international tourism. The tourism businesses should take note of the changes being witnessed in consumer behaviour such as trips closer to home or proximity travel, bookings closer to the departure dates of the trip, or a preference to travel by car in order to tailor their products to the needs of the new-normal clients. This will enhance their competitiveness and sustainability as well as redistribute opportunities for employment.

Covid-19 has reshaped the work structure of many economic sectors including tourism, where employees would remotely work from home. The tourism sector calls for creative, talented, and proficient people, with infrastructure that is well-developed in place. The government should engage experts with an array of techniques to stimulate income generation, employment opportunities, and revenue for the local population through support for digital platforms.

Governments should support economic diversification in the medium and longer-term, where possible. Since high dependence on one sector or region increases vulnerability, it is imperative that governments pursue economic diversification through regional integration, targeted education, and training programs to boost resilience and mitigate the cost of shocks in areas prone to over-tourism. Education and training are key ingredients to the success of sustainability initiatives.

\section{Acknowledgement}

I am grateful to Mr. Amos Kibet, Mr. Sammy Chepkilot, and Mr. Joseph Kibet for their moral support and assistance in the development of this paper, which contributed significantly to the improvement of the manuscript.

\section{References}

Akama, E. (2017). International Tourism Receipts and Economic Growth in Kenya 1980 -2013. MPRA. Paper No. 78110.

Alhowaish, A.K. (2016) Is Tourism Development a Sustainable Economic Growth Strategy in the Long Run? Evidence from GCC Countries. MDPI. Sustainability, 8 (7), 605.

Baumöhl, E., and Lyócsa, Š. (2009) Stationarity of Time Series and the Problem Of Spurious Regression. MPRA. Paper No. 27926.

Dartmouth (2015) What is Sustainability? Retrieved August 12, 2020, from http://www.dartmouth.edu/ cushman/courses/engs41/Mark\%20Borsuk\%27s\%20version\%20of \%20course/Lectures/Lecture13_ENGS41_post.pdf.

Dushenko, M., Bjorbaek, C., \& Steger-Jensen, K. (2019). Application of a Sustainability Model for Assessing the Relocation of a Container Terminal: A Case Study of Kristiansand Port. Sustainability, 11, 87; doi:10.3390/su11010087.

Granger, C. (1988). Some recent Developments in a Concept of Causality. Journal of Econometrics, $39,199-211$. 
ILO (2016) Sustainable Tourism: A Driving Force Of Job Creation, Economic Growth And Development. Retrieved August 11, 2020, from https://www.ilo.org/global/about-theilo/newsroom/news/WCMS_480824/lang--en/index.htm.

ILO (2017) ILO Guidelines On Decent Work And Socially Responsible Tourism. International Labour Office, Sectoral Policies Department - Geneva. 10.05.3.

IMF (2020) World Economic Outlook (WEO), April 2020. Retrieved August 10, 2020, from https://knoema.com/IMFWEO2020Apr/imf-world-economic-outlook-weo-april-2020.

Ivanov, S. H., and Webster, C. (2007) Measuring the Impact of Tourism on Economic Growth. Tourism Economics, 13(3), 379-388.

Jayathilake, P.M. B. (2013) Tourism and Economic Growth in Sri Lanka: Evidence From Cointegration And Causality Analysis. International Journal of Business, Economics and Law, 2(2). ISSN 2289-1552.

Johansen, S., \& Juselius, K. (1990). Maximum Likelihood Estimation and Inference on Cointegration-With Applications to the Demand for Money. Oxford Bulletin of Economics and Statistics, 52(2), 169-210.

Kenya Economic Outlook (2020) Kenya-GDP. Retrieved from https://www.focuseconomics.com/countries/kenya.

Kibara, O. N., Odhiambo, N. M., \& Njuguna, J. M. (2012). Tourism and Economic Growth In Kenya: An Empirical Investigation. International Business \& Economics Research Journal (IBER), 11(5), 517-528.

Kline, R.B. (2011). Principles And Practice Of Structural Equation Modeling (5th ed., pp. 3-427). New York: The Guilford Press.

Longyu, S., Linwei, H., Fengmei, Y., and Lijie, G. (2019) The Evolution of Sustainable Development Theory: Types, Goals, and Research Prospects. Sustainability,11, 7158; doi:10.3390/su11247158.

Maden, I.S., Bulgan, G., and Yildirim, S. (2019). The Effect of Tourism Sector on Economic Growth: An Empirical Study on Turkey. Journal of Yasar University. 14/55, 215-225.

Maftuhah, D.I., and Wirjodirdjo, B. (2018) Model for Developing Five Key Pillars of Sustainable Tourism: A Literature Review. Human-Dedicated Sustainable Product and Process Design: Materials, Resources, and Energy. AIP Conference Proceedings, 040009; https://doi.org/10.1063/1.5042979

Magical Kenya (2020) Tourism Industry Post CoronaVirus. Retrieved August 10, 2020, from https://magicalkenya.com/news/the-industry-must-re-think-its-strategy-in-order-to-survivepost-coronavirus.

Maingi, S. W. (2020) Case Study 6: Mainstreaming Overtourism Education for Sustainable Behavioral Change in Kenya's Tourism Industry Context. In Séraphin, H., Gladkikh, T., Thanh, T. Eds. (2020) Overtourism: Causes, Implications and Solutions. ISBN 978-3-030-42458-9.

Manzoor, F., Wei, L., Asif, M., Haq, M., \& Rehman, H. (2019). The Contribution of Sustainable Tourism to Economic Growth and Employment in Pakistan. International Journal of Environmental Research and Public Health, 16. 3785. 10.3390/ijerph16193785.

Ministry of Health (2020) CS Health Launches Primary Health Strategic Framework As A Pillar To Achieve UHC Nakuru July 16, 2020. Retrieved August 12, 2020 from https://www.health.go.ke/cs-health-launches-primary-health-strategic-framework-as-a-pillar-toachieve-uhc-nakuru-july-16-2020.

Ministry of Tourism and wildlife (2020) Impact Of Covid-19 on Tourism in Kenya, the Measures taken and the Recovery Pathways. Research Report.

Obulutsa, G., and Mohammed, O. (2020) Kenya's GDP growth to plunge to $1.5 \%$ in 2020 due to coronavirus -World Bank. Retrieved August 14, 2020, from https://af.reuters.com/article/idAFKCN22B0SG-OZABS.

OECD (2020) Tourism Policy Responses to the Coronavirus (COVID-19). Retrieved August 15, 2020, from https://www.oecd.org/coronavirus/policy-responses/tourism-policy-responses-tothe-coronavirus-covid-19-6466aa20.

Ohlan, R. (2017) The relationship between tourism, financial development and economic growth in India. Future Business Journal, 3, 9-22. 
Parliamentary Budget Office (2020) The COVID 19 global pandemic: Impact to the economy and policy options. Special Bulletin No. 1/2020.

Phiri, A. (2015). Tourism and Economic Growth in South Africa: Evidence from Linear and Nonlinear Co-integration Frameworks. Managing Global Transitions, 14, 31-53.

Republic Of Kenya (2020a) Ministry Of Tourism and Wildlife Strategic Plan 2018-2022. Revised April 2020. Retrieved from http://www.tourism.go.ke/wp-content/uploads/2020/06/DraftMTW-Strategic-Plan-2018-2022-June-2020-1.pdf.

Republic of Kenya (2020b) Draft Revised National Tourism Policy, 2016 On Enhancing Sustainable Tourism In Kenya. Working Document. Retrieved from http://www.tourism.go.ke/wpcontent/uploads/2020/07/Policy-Tourism-Draft-May-2020-.pdf.

Statista (2020) Predicted Employment Loss In The Travel And Tourism Industry Due To The Coronavirus (Covid-19) Pandemic Worldwide In 2020, by Region. Retrieved from https://www.statista.com/statistics/1104835/coronavirus-travel-tourism-employment-loss.

Tabash, M. (2017). The Role of Tourism Sector in Economic Growth: An Empirical Evidence From Palestine. International Journal of Economics and Financial Issues, 7, 103-108.

The Parliament of Kenya (2020) Unpacking Of The Budget Policy Statement \& Medium-Term Debt Management Strategy 2020. Retrieved from http://www.parliament.go.ke/sites/default/files/202003/Unpacking\%20of\%20BPS\%202020\%20final.pdf.

Trading Economics (2020) Kenya GDP Per Capita. Retrieved from https://tradingeconomics.com/kenya/gdp-per-capita.

Turgut, B., and Yilmaz, A. (2015). The Relationship Between Tourism And Economic Growth In Greece Economy: A Time Series Analysis. CMSS, 3(1).

UNCEEA (2016) Measuring Sustainable Tourism: Developing a statistical framework for sustainable tourism. Paper for submission to the United Nations Committee of Experts on EnvironmentalEconomic Accounting (UNCEEA) June 2016 Indicators for sustainable tourism. Retrieved from https://unstats.un.org/unsd/envaccounting/ceea/meetings/eleventh_meeting/SM-11-2a.pdf.

UNCTAD (2020) Covid-19 and Tourism. Assessing the Economic Consequences. Retrieved from https://unctad.org/en/PublicationsLibrary/ditcinf2020d3_en.pdf.

UNDP (2020) Rapid Livelihood Assessment - Impact of COVID-19 Crisis in the Maldives. Retrieved from file:///C:/Users/user/AppData/Local/Temp/UNDP-MV-Rapid-Livelihood-AssessmentImpact-of-COVID-19-Crisis-in-the-Maldives-summary-2020-1.pdf.

UNWTO (2020) Sustainability as the New Normal" a Vision for the Future of Tourism. Retrieved from https://www.unwto.org/covid-19-oneplanet-responsible-recovery.

WCED (1987). Report of the World Commission on Environment and Development: Our Common Future. UN Documents: Gathering a Body of Global Agreements. Google Scholar.

WTTC (2020) World Travel and Tourism Council Data. Retrieved from https://knoema.com/WTTC2019/world-travel-and-tourism-council-data 